\title{
Documentation of microalgal species from selected regions of Peshawar valley, Khyber Pakhtunkhawa (KPK), Pakistan
}

\author{
Komal Salah-Ud-Din ${ }^{1}$, Muhammad Shuaib ${ }^{2 *}$ and Fida Hussain ${ }^{1,3}$ \\ 1. Department of Botany, Qurtaba University Peshawar, KPK- Pakistan \\ 2. School of Ecology and Environmental Science, Yunnan University, NO.2 North Cuihu road, Kunming, Yunnan, \\ 650091, PR-China \\ 3. School of Resources, Environmental and Chemical Engineering Nanchang University, Nanchang Jiangxi- China \\ *Corresponding author's email: zeyadz44@yahoo.com
}

Citation

Komal Salah-Ud-Din, Muhammad Shuaib and Fida Hussain. Documentation of microalgal species from selected regions of Peshawar valley, Khyber Pakhtunkhawa (KPK), Pakistan. Pure and Applied Biology. Vol. 6, Issue 2, pp561-575. http://dx.doi.org/10.19045/bspab.2017.60058

\begin{tabular}{llll}
\hline \hline Received: 07/02/2017 & Revised: 12/04/2017 & Accepted: 15/04/2017 & Online First: 19/04/2017 \\
\hline \hline
\end{tabular}

\section{Abstract}

In the present research work different micro-algal species is collected from the selected areas of Peshawar valley. The current investigation included altogether 30 species of algae belonging to 4 classes having 16 genera are collected from various fresh water habitats in the Peshawar District including Gulbahar, Hayatabad and Ringroad. Among various classes Bascillariophyceae was most prevalent and represented by 16 species (53.3\%), Cyanophyceae are represented by 8 species (26.6\%), Chlorophyceae are represented by 4 species $(13.33 \%)$ and Zygnemophyceae are represented by 2 species (6.66\%). The present research shows that the district Peshawar is rich of algal flora and further studies and research is needed in the other sites of valley.

Keywords: Microalgae; Documentation; Selected region; Peshawar

\section{Introduction}

The term algae epitomize a large group of different organisms from different phylogenetic groups, representing many taxonomic divisions. In general algae can be referred to as plant-like organisms that are usually photosynthetic and aquatic, but don't have true roots, stems, leaves, vascular tissues and have simple reproductive structures. Mostly algal species are eukaryotic and have chloroplast doing photosynthesis within the membrane bounded organelles. All the algal species have different structure of chloroplast have no same structures [1]. Algae are the unicellular or multicellular, photosynthetic organism having no true roots, stems, leaves found mostly in fresh water and moist places [1]. In the earth algae is one of the most important photosynthetic organism and the aquatic food web formed by the algae which support different animals [2]. Billion years ago it is the first plant species come to the earth and photosynthesized [3]. Most of the algae present in water but also live on soils, trees, animals, some inside the porous rocks like sandstone and limestone. Algal species is a unique life style and grow in extreme environments i.e. in high temperature and low temperature it do has survival good [4]. Algae have different size and habitat, some are large and some are small up to thousand 
species were put into the small pin head [5]. Algae are mostly in different forms and shapes, one cell algae when combine together formed a colony and these are worked together independently. The multicellular algae the cell join end to end or formed branched making filaments and complexes algae have their specialized cells [6].

Different researchers worked in different parts of Khyber Pakhtunkhwa Pakistan. From the district Peshawar the species of Bacillariophyaceae reported by [7]. They recorded 20 genera with 86 species of Bascillariophyceae. In this study 17 species is recorded maximum [8] reported order ulotrichales from District Peshawar, KPK. A total of 30 fresh water species belong to 14 genera is reported from river Shah Alam district Peshawar, in which the most and maximum stake is shown by Chlorophyceae $83 \%$ in the total collection during the research by [9]. Peshawar is the capital and largest city of Khyber Pakhtunkhawa Province. Peshawar valley lies in between $33^{\circ} 44$ and 34015 towards in north latitude and 71022 , and $71^{\circ} 42$ towards east longitude. The total areas of district Peshawar are 1257sq km. District Peshawar has boundary with of about $40 \mathrm{~km}$ in West with Afghanistan, in the north with Mohmmand agency, in east with District Kohat and Semi tribal areas in south. The district is mostly fertile plain. In the recent geological time Peshawar is covered by consolidated deposits which are sands, silts, and gravel. The central part of the district consists of fine alluvial deposits.

\section{Material and methods}

The present research work aims on the collection, identification, classifications and distribution of algae in selected parts (Gulbahar, Ring road, Hayatabad) of district Peshawar. Study includes on different Genera and their species found in the designated area of district Peshawar. The study furthermore expands to the measurement of various chemical and Physical properties of water, which algal floras are inhibited. The comparative inquiries of algae floras are primarily dependence on polluted, slightly polluted and unpolluted water.

\section{Species sampling}

The water and algal species samples is collected from the selected regions in Peshawar. The species collection is done with Squeezing, directly put in bottle, hand picking and Scarping the aquatic flora. These collected samples are than brought in plastic bottles have size of 1 liter and polythenes bags.

\section{Preservation of species}

The algae collections were preserved with $3 \%$ formalin solutions in glass bottles. $\mathrm{pH}$ of water is recorded on the spot with during collection in the research areas. Similarly the temperature of air and water were also noticed at time of collection.

\section{Species identifications}

Algal species were identified through making fresh slide\& observe through microscope. Prescott is used for the identification. All the collected water samples were analyzed in PCSIR lab. Peshawar and study its chemical and physical properties. Algal species is the preserved in put in the Herbarium of Botany Department, Islamia College University Peshawar, Pakistan. 
Table 1. Name of classes, number of classes, species and its percentages

\begin{tabular}{|l|l|c|c|c|}
\hline S.No. & Class & No. Of Genera & No. Of Species & Species \%age \\
\hline 1. & Bascilariophyceae & 10 & 16 & $53.3 \%$ \\
\hline 2. & Cyanophyceae & 01 & 08 & $26.6 \%$ \\
\hline 3. & Chlorophyceae & 04 & 04 & $13.3 \%$ \\
\hline 4. & Zygnemophyceae & 01 & 02 & $6.6 \%$ \\
\hline Total & $\mathbf{0 4}$ & 16 & 30 & $100 \%$ \\
\hline
\end{tabular}

Table 2. Class, Genus and species in the selected area

\begin{tabular}{|c|c|c|c|}
\hline S.No & Class & Genus & Species \\
\hline 1 & Bascillariophyceae & Gomphonema & G.sphaerophorum \\
\hline 2 & & & G.ventricosum \\
\hline 3 & & & G.olivaceum \\
\hline 4 & & Cymbella & C.cymbiformis \\
\hline 5 & & & C.tumida \\
\hline 6 & & Diatoma & D.anceps \\
\hline 7 & & & D.vulgaris \\
\hline 8 & & Navicula & N.cryptocephala \\
\hline 9 & & & N.salinarum \\
\hline 10 & & Synedra & S.ulna \\
\hline 11 & & & S.rumpens \\
\hline 12 & & Nitzchia & N.hungaria \\
\hline 13 & & Flagilaria & F.capucina \\
\hline 14 & & Cymatopleura & C.solea \\
\hline 15 & & Tabellaria & T.flocculosa \\
\hline 16 & & Denticula & D.tenuis \\
\hline 17 & Chlorophyceae & Chlamydomonas & C.globosa \\
\hline 18 & & Cosmarium & C.contractum \\
\hline 19 & & Oocystis & O.borgei \\
\hline 20 & & Ulothrix & U.cylindricum \\
\hline 21 & Cyanophyceae & Oscillatoria & O.sancta \\
\hline
\end{tabular}

Taxonomic description

\section{Genus 1}

\section{Oscillatoria}

It is a genus of filamentous cyanobacterium. It is commonly found in watering thoughts waters, and is mainly blue- green or browngreen, Reproduction occurs through fragmentation called hormogonia. Oscillatoria uses photosynthesis to survive and reproduce.

Key to the Species

1. Trichome $12 \mu \mathrm{m}$ broad and $6 \mu \mathrm{m}$ long (O.sancta)

2. Granulles present uniformly (O.tenuis)
3. No constrictions at cross walls (O.princeps)

4. Cell contents granular (O.formosa)

5. Transverse septa not granulated (O.chilkensis)

6. Trichome may be straight or curved (O.amphibia)

7. Cell granular at the cross walls (O.agardhii)

8. Trichomes $0.8-1.3 \mu$ in diameter, $5-7 \mu$ long (O.angusta) 


\section{Oscillatoria sancta (Kutzing) Gomonot 1892}

Thallus dark blue green,mucillagenous sheath present, the thallus trichome is straight or less, the cross walls are mostly constricted and board 12 micro-meters broad and $6 \mu \mathrm{m}$ long, end cell hemispherical and attenuated, slightly capitate with a thickened membrane.

\section{Oscillatoria tenuis Agardhx Gomont 1892}

Thallus blue green,trichome straight, constriction not present at the cross walls, cells $6 \mu \mathrm{m}$ broad and $4 \mu \mathrm{m}$ long, granule present uniformly.

\section{Oscillatoria princeps Vucher ex Gomont} 1982

Thallus blue green, slightly curved, constriction absent at the cross walls, $6 \mu \mathrm{m}$ long and $24 \mu \mathrm{m}$ broad, end celssightly capitate.

\section{Oscillatoria formosa (Bory ex Gomont) 1892}

Trichomes straight or flexuous, not tapering at the end; septa conspicuously constricted, 4-6 $\mu \mathrm{m}$ broad, apex neither capitate nor calyptrate, obtusely conical; cells almost subquadrate to quadrate, $2.0-4.0 \mu \mathrm{m}$ long; cell contents bright blue-green, granular.

\section{Oscillatoria chilkensis (Biswas) 1932}

Thallus yellowish blue-green; trichomes 2.5$5.0 \mu \mathrm{m}$ in diameter, undulated, somewhat curved, slightly constricted at cross walls; apex of trichomes shortly tapering; apical cell narrow; obtusely rounded not pointed, capitate; cells shorter than broad, 2-4 $\mu \mathrm{m}$ long, 4-6 $\mu \mathrm{m}$ broad; transverse septa not granulated; cell contents homogenous, pale blue green.

6. Oscillatoria amphibia (C.Agardh 1827) Gomont

Trichome straight or curved not attenuated towards apex, blue-green or pale-green. Cells 2-3(-3.5) $\mu \mathrm{m}$ wide, 4-8.5 $\mu \mathrm{m}$ long, 2-3 times longer than wide, cross walls not narrowed, often with granules; end cells rounded, not capitate, calyptra absent.

\section{Oscilatoria agardhii (Gomont) 1892}

Trichomes interwoven to form a blue-green plant mass occasionally found floating free; straight throughout their entire length, briefly tapering at the anterior end, which is usually capitate, but frequently smooth. Apical cell truncate-conical, with or without a calyptra. Cells (3.4)-5.5-6 $\mu$ in diameter and not constricted at the cross walls, which are granular; their length from $1 / 2$ to approximately equal their width.

\section{Oscillatoria angusta (Koppe) 1924}

Trichomes loosely entangled to form a thin plant mass, or solitary; not a paring towards the apex; apical cell bluntly rounded, without a calyptra and not capitate; cells (0.8)-1.1-1.3 $\mu$ in diameter, (5)-7-8-(10) $\mu$ long, not conspicuous at the cross walls; contents nearly colorless, without pseudovacuoles or conspicuous granules. Entangled and intermingled with other species of Oscillatoria and miscellaneous blue-green algae, forming a slimy layer in shallow water.

\section{Genus 2}

\section{Ghomphonema}

Gomphonema is a genus of diatoms (Bacillariophyta) with about 100 species in fresh water. They are unicellular diatoms that are stuck mainly to simple or branched gelatin stalks. The cells have typical diatoms shell of two counters. Asexual reproduction occurs through typical dichotomy of diatoms. Sexual reproduction occurs through anisogamy.

Key to the species

1. Axial area is narrow and straight (G.sphaerophorum)

2. Valves are lanceolate and clavate (G.ventricosum)

3. Striae are radiate (G.olivaceum) 


\section{Gomphonema sphaerophorum (Ehrenburg) 1845}

Valves are clavate with a distinctly capitate headpole and a narrow foot pole. Axial area is narrow, becoming linear-lanceolate in smaller specimens. Central area is transversally elliptic and incomplete. A stigma is present opposite a single shortened striate; the raphe is undulate and lateral. Striae are nearly parallel mid-valve, becoming radiate at the apices. Areolae are distinctly punctate and visible in LM, measuring $25-27$ in $10 \mu \mathrm{m}$. A distinct pore field is present at the foot pole.

\section{Gomphonema ventricosum (Gregory)} 1856

Length is $33-47 \mu \mathrm{m}$, width is $10-12$ $\mu \mathrm{m}$.Valves are lanceolate-clavate, broadest at the center with a broadly-rounded headpole and rounded footpole. The axial area is narrowly lanceolate, forming a distinct, mostly irregular, elliptical central area. A single stigma is present. The central area is formed by $4-5$ shortened striae on either side. The raphe is weakly undulating and lateral. Striae are punctate, uniseriate and radiate (becoming parallel in some specimens).The apical pore field is distinct and bilobed. Septa are frequently observed.

\section{Gomphonema olivaceum (Dawson ex Ross and Sims) 1978}

Length is $14-40 \mu \mathrm{m}$, width is $5-8 \mu \mathrm{m}$. Valves are cavate with a broadly rounded headpole and a narrow footpole. The valve tapers more strongly towards the footpole than to the headpole. The raphe is fusiform and lateral. The raphe terminates internally distantly from the apices.The axial area is narrow, straight and expanded laterally to form a rectangular central area boarded by shortened striae at or near the margin. Stigma is absent. Striae are costate and individual areoale are not visible in the LM. Striae are radiate.

\section{Genus 3}

Chlamydomonas

Chlamydonomas is a genus of blue green algae consisting of unicellular flagellates. It is found in stagnant water and on damp soil in fresh water, sea water and even in snow as snow algae.

Key to the species

1. Small basal pyrenoid is present $(C$. globosa)

1. Chlamydomonas globosa (J.Snow) 1902 Cells solitary with 2 equally sized apical flagella, almost spherical, without a papilla; chloroplast cup-shaped with a small basal pyrenoid; cells 5-9 $\mu \mathrm{m}$ in diameter.

\section{Genus 4}

\section{Tabellaria}

Tabellaria is a genus of diatoms (Bacillariophyta).They are cuboid in shape, frustules (siliceous cell walls) are attached at the corners so that the colonies assume a zigzag shape.

Key to the species

1. Thestriae is alternate (T.flocculosa)

1. Tabellaria floccuosa (Roth) Kutzing 1844

The length is about $11-83 \mu \mathrm{m}$ and width is about 3.2-8.8 $\mu \mathrm{m}$. Valvesarre linear with an inflation in the center of the valve and capitate to slightly capitate apices. The medial inflation of the valve is wider than the apices. Striae are usually parallel, but can be slightly radiate in the medial inflation. The axial area is narrow and linear. The central area is small and rhombic. Short marginal spines are present, although the spines are difficult to see in LM. Cells are jointed in colonies, usually in zigzagor stellate formations. Frustules are rectangular in girdle view.

\section{Genus 5}

\section{Chlosterium}

Closterium is a cresent-shaped or elongated desmid. Some species are straight and needle like but most are broader or curved ends. The desmid is formed of two hemicells 
that are also mirror images of each other but there is only a single central nucleus. Each semi cells has one or two axial, ridged chloroplasts with at least one pyrenoid.

\section{Key to the species}

1. Chloroplast contains 5-10 laminae (C.lanceolatum)

2. Two chloroplasts are present divided by nucleus (C.moniliferum)

\section{Closterium lanceolatum Kutzing ex} Ralfs (1848)

Cell body slightly curved, inner side slightly straight; L/W=6-8;Cholroplasts with 5-10laminae and Transparent, smooth cell wall, semi cells has each 6-8 pyrenoids having 200-540 micro-meter long, 28-(3052)-79 $\mu \mathrm{m}$ wide.

\section{Closterium moniliferum (Bory) Ehrenb.exRalfs, 1848}

Cells solitary, lunate , moderately curved, inner margin tumid in mid region, sometimes straight or slightly concave, tapering to rounded apices; 2 chloroplasts divided by nucleus, each with 3-6 longitudinal ridges and 2-10 axial pyrenoids , walls colorless, very delicate striated; spherical terminal vacuoles within broad cell ends; cells 35-55 $\mu \mathrm{m}$ wide, 210-350 $\mu \mathrm{m}$ long.

\section{Genus 6}

\section{Navicula}

Navicula is a genus of boat-shaped algae primarily aquatic, eukaryotic, photosynthetic organisms, ranging in size from a single cell. Navicula is a diatom and it plays an important role in global ecology, producing about a quarter of all the oxygen within Earth's biosphere. The genus Navicula of diatoms is comprises over 1,200 species.

\section{Key to the species}

1. The raphe is straight, with "droplike"expanded external proximal end (N.cryptocephala)

2. Striae are lineate, radiate and arched (N.salinarun)

\section{Navicula cryptocephala (Kutzing) 1844}

Length ranges from 21-34 $\mu \mathrm{m}$ whereas width ranges from 5.2-5.5 $\mu \mathrm{m}$. protracted apices of Valves are lanceolate, straight and narrow axial area. The central part is circular and large. Areolae is sometime perceptible under L.M. \& number approximately 35 in $10 \mu \mathrm{m}$.

\section{Navicula salinarum (Grunow) 1880}

Its length is about $25-35 \mu \mathrm{m}$ while width is about 8-9 $\mu \mathrm{m}$. Valves are broadly ellipticallanceolate with produced, rostrate ends. The axial area is straight and relatively narrow, enlarging to form an elliptical to ellipticallanceolate central area. The central area is formed by alternating long and short striae in the center of the valve. Striae are lineate, radiate and arched, becoming parallel to the apices.

\section{Genus 7}

\section{Denticula}

Cells of Denticulla are relatively small and usually solitary, but they may occur in short chains. Each cell contains two plastids on either side of the transapical plane near the center of the cell. Valves are symmetrical to both the apical and transpical axes and are linear to lanceolate with a fibulate raphe on each valve that is slightly eccentric on the valve surface.

Key to the specie

1. Valves are lanceolate to elliptical lanceolate (D.tenuis)

\section{Denticula tenuis (Kutzing) 1844}

Its length is about $12-20 \mu \mathrm{m}$ and width is about $4 \mu \mathrm{m}$. Valves are lanceolate to elliptical-lanceolate, with protracted apices. The raphe is distinct, positioned off center and contained within a canal. Transapical costae are distinct. The striae are punctate.

\section{Genus 8}

Cymbella

Cymbella is a diatom genus in the family Cymbellaceae.Typically benthic, often attach to the substrate with a mucilaginous stalk.Members of this genus can form "rock 
snot" in creeks and rivers by forming colonial aggregates.

Key to the specie

1. Valves are crescent to spindle shaped (C.cymbiformis)

2. Cells are broadly-lanceolate (C.tumida)

1. Cymbella cymbiformis (C.Agardh) 1830

Valves are cresent to spindle shaped, both sides are obviously asymmetric carry the side edge to appear projection, belly side edge to arise straight, middle projects slightly partly, and tapering with rounded ends, 3-100 $\mu \mathrm{m}$ long, 9-14 $\mu \mathrm{m}$ in diameter, narrow in the pivot district, sewn and partial to the belly side, a single point and line among them, striae radical, 8-10 in $10 \mu \mathrm{m}$.

\section{Cymbella tumida}

Cells are broadly-lanceolate. Dorsal margin is convex and rounded while ventral margin is slightly linear. Raphe is middle to the valve bent towards the margin. Valve has blunt end with mild constriction that formed pin like ends.

\section{Genus 9}

\section{Diatoma}

Diatoms are a major group of algae and are among the most common types of phytoplankton. Diatoms are unicellular although they can form colonies in the shape of filaments or ribbons, fans, zigzags or stars. Diatoms are producers within the food chain.

\section{Key to the species}

1. The sternum is central and well defined (D.ancepas)

2. The axial area is linear, very narrow (D.vulgaris)

\section{Diatoma ancepas (Ehrenberg) 1843}

The length is about $10-46 \mu \mathrm{m}$ and width is about 5.2-7.0 $\mu \mathrm{m}$. Valves apically and transapically symmetrical; linear with capitate ends. Small valves may be more elliptical with less capitate ends than larger valves. Valves possess both primary and secondary costae, which measure 3.3-4.9 in $10 \mu \mathrm{m}$. Striae are visible in LM but individual areolae cannot be observed. The sternum is central and well-defined. Each valve has a single, sub-apical rimoportula.

\section{Diatoma vulgaris (Bory) 1824}

Its length is about $15-60 \mu \mathrm{m}$ and width is about 8-12 $\mu \mathrm{m}$. Cells form zigzag colonies. Frustules are in girdle view. Valves are elliptical to elliptical-lanceolate with broadly rounded subrostrate ends, 8-12 $\mu \mathrm{m}$ wide, and 15-60 $\mu \mathrm{m}$ long. Transapical ribs 6-10 in $10 \mu \mathrm{m}$. Striaeuniseriate, $45-50$ in $10 \mu \mathrm{m}$, consisting of small poroid areolae. The axial area is linear, very narrow.

\section{Genus 10}

\section{Flagilaria}

Flagilaria is a genus of fresh water and salty water diatoms. It is usually a colonial diatom, forming filaments of cells mechanically joined by protrusions on the face and in the center of their valves.

Key to the specie:

1. It is fresh water specie (F.capucina)

1. Fragilaria capucina (Desmazieres) 1830 This is very variable taxa, but is not normally confused with other Fragilaria. The elongated shape and the presence of a node are diagnostic. Length varies from 10-100 microns and width varies from 2-6.5 microns and striae are about 9-22/10 microns. It is fresh water specie.

\section{Genus 11}

Nitzschia

Nitzschia is a common pennate marine diatom. It i found mostly in colder water and is associated with both Artric and Anartric polar sea ice where it is often found to be the dominant diatom.

\section{Key to the species}

1. Theraphae is excentric (N.hungarica)

\section{Nitzschia hungarica (Grunow) 1862}

Its length is about $35-100 \mu \mathrm{m}$ while width ranges from 5-9 $\mu \mathrm{m}$. Valves are linear and slightly concave in the middle. The apices are protracted slightly and bluntly rounded. The raphe is excentric; with fibulae numbering 8-11 in $10 \mu \mathrm{m}$. Striae appear 
costate, rather than distinctly punctate. A longitudinal fold is present and extends the length of the valve.

\section{Genus 12}

\section{Ulothrix}

Ulothrix is a genus of filamentous green algae, generally found in fresh and marine water. They are eukaryotic and unicellular. Reproduction is normally vegetative. The plant body consists of unbranched, uniseriate filaments.

Key to the specie

1. Filaments long, curved and lightly entangled (U. cylindricum)

\section{Ulothrix cylindricum}

Filaments are long, curved and lightly

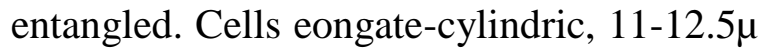
in diameter, $2 \frac{1}{4}$ to 3 times longer than wide; the wall thin and not constricted at the joints. Chloroplast a broad band, nearly equal to the cell in length and folded around $3 / 4$ of the cir-comference; pyrenoids $2-5$.This specie should be compared with Ulothrixaequalish Kuetzing which has thick walls, shorter cells fewer pyrenoids, and a different form of chloroplast.

Genus 13

\section{Cosmarium}

Cosmarium is a non-motile, fresh water member of division Chlorophyta. Cosmarium is a relatively large unicell characterized by an isthmus. A single haploid nucleus occupies the isthmus.

Key to the specie:

1. Singlepyrenoid in each semi cell $(C$. contractum)

\section{Cosmarium contractum (Kirchner)}

Cell body 28-41 $\mu \mathrm{m}$ long, 18-31 $\mu \mathrm{m}$ wide, isthmus 5.3-8.7 $\mu \mathrm{m}$ wide, $\mathrm{L} / \mathrm{W}=1.5$; semi cells broad ellipsoid, laterally circular; cell wall smooth or finely dotted, a single pyrenoid in each semicell.

\section{Genus 14}

Oocystis

Oocystis is a planktonic genus of the mostly fresh water green algae of the family Oocystaceae.

Key to the specie

1. Chloroplast 1-4 depending upon age and grooved $(O$. borgei)

\section{Oocystris borgei (J. Snow)}

Cells solitary or in a colony of 2,4 or 8 densely packed and tetrahedrally arranged cells; cells broadly ovoid or ellipsoidal with broadly rounded apices without polar wall thickening; 8.5 to $15 \mu \mathrm{m}$ wide, $11-16 \mu \mathrm{m}$ long; chloroplast 1-4 depending on age , grooved, each with a pyrenoid.

\section{Genus 15}

\section{Cymatopleura}

Frustules biraphid, linear to elliptical in outline. A common species (C.solea (Bre) W.Smith) is constructed about the central portion of the valve, while C. cochlea is twisted about the apical axis, symmetrical or a symmetrical to the transapical axis. Striae distinct.

\section{Key to the specie}

1. The raphe is contained in a canal around the margin of the valve (C.solea)

\section{Cymatopleura solea (W.Smith) 1851}

Length is about $56-280 \mu \mathrm{m}$ and width is about 13-24 $\mu \mathrm{m}$ at the mid-section, 15-36 $\mu \mathrm{m}$ at the broadest point. Valves are broadly linear with a central constriction and tapering to blunt ends. Alar canals and ribs number 6-9 in $10 \mu \mathrm{m}$. Striations between the ribs are evident by fine, but not distinctly punctate striae. The raphe is contained in a canal around the margin of the valve. Undulations oriented across the face of the valve, occur the length of the valve.

\section{Genus 16}

\section{Synedra}

Synedra is a rod-shaped and bilaterally symmetrical. The walls of algae's diatoms contain overlapping halves that are 
composed of silica. It is a single cell alga that grows in the spray-like clusters.

\section{Key to the specie}

1. Striae are parallel (S.ulna)

2. Colonies rib-bone likes (S.rumpens)

1. Synedra ulna (Nitzsch) Ehrenberg 1982

Valves linear with gradually attenuated to rostrate or sometimes somewhat restratewedge-shaped end; axial area narrow; central area not much longer than broad, often almost square, sometimes very short striae on the margins; striae parallel; length of valve $75-100 \mu \mathrm{m}$, sometimes as short as $50 \mu \mathrm{m}$ or up to $300 \mu \mathrm{m}$, breadth $15-9 \mu \mathrm{m}$, striae 11-14 in $10 \mu \mathrm{m}$.

\section{Synedra rumpens (Kutzing)}

The lanceolate is irregular curved sometime or fusiform. Breadth 3-4micrometer and length 25-63micrometer.Striae parallel throughout per $10 \mathrm{~cm}$ is 18-20. Rib bone like colonies shown in their faces.

\section{Results and discussions}

During the course of investigation it has been observed that there were variations of algal species in different areas of Peshawar. The collection was done from different regions of Peshawar including Gulbahar, Hayatabad and Ringroad. About 30 species of algae were identified from these regions and were belonging to 4 classes Bascillariophyceae, Chlorophyceae, Cyanophyceae and Zygnemophyceae shown in the Figure 1. Among these classes the major representing classes were Bascillariophyceae with $53.3 \%$ species, Cyanophyceae with $26.6 \%$ species, Chlorophyceae with $13.3 \%$ species and Zygnemophyceae with $6.6 \%$ species respectively. Bascillariophyceae members were represented by 10 genera i.e. Ghomphonema with 3 species (10\%), Cymbella with 2 specie $(6.66 \%)$, Diatoma with 2 species $(6.66 \%)$, Naviculla with 2 species $(6.66 \%)$, Synedra with 2 species (6.66\%), Nitzchia with 1 specie (3.33\%), Fagilaria with 1 specie $(3.33 \%)$,
Cymatopleura with 1 specie (3.33\%), Tabellaria with 1 specie $(3.33 \%)$, Denticula with 1 specie $(3.33 \%)$. Cyanophyceae members were represented by only 1 genus i.e. Oscillatoria with 8 species $(26.66 \%)$, Chlorophyceae members were represented by 4 genera i.e. Chlamydomonas with one (1) specie $(3.33 \%)$, Cosmarium with 1 specie (3.33\%), Oocystis with 1 specie (3.33\%), ulothriz with 1 specie (3.33\%). Zygnemophyceae members were represented by 1 genera i.e. Chlosterium with 2 species $(6.66 \%)$ shown in the Figure 2. Although 30 species were recorded and identified from these regions but still more research and study will be required. As there are different authors who worked on the algae belonging to these regions. [9] thirty fresh water species have 14 genera is reported from Shah Alam district Peshawar, and Chlorophyceae shows maximum share about $83 \%$ in total collection during the research study. [10] reported Ulotrichales from District Peshawar, KPK Pakistan. [7] reported 86 species of Bascilllariophyceae belong to 20 genera and the maximum share of navicula having 17 species from district Peshawar. Similarly 73 algal fresh water species and their morpho-taxonomic description belonging to 9classes, 17 order, 25 families and 34 genera, amongst them 65 $\%$ algal species belong to Chlorophyta and $12 \%$ species belong to Cyanophyta, from the adjoining area of KPK, Mardan explained by [11]. Similarly [8] worked on fresh water green filamentous algae from the different lakes and ponds of Sindh and reported 31 species from fresh water of river and ponds of Chrysophyta and Chlorophyta. Various unexplored blue green algae species were reported from various parts of KPK and Punjab by $[12,13]$ explained 138 species of Chlorophycean species, among all these species 74 species were belong to Chlorococcales (53.6\%), 3\% species belongs 
to Cladophorales and Chaophorales each, and 1 species belong to Sphaeropleales.

Similar study from Dir lower by [14] explained 40 fresh water algal species in the different areas of Dir lower belong to 27genera, 18orders, and 12 classes. Among them 9spp of Conjugatophyceae (22.5\%), $7 \mathrm{spp}$ of Cyanophyaceae (17.5\%), $6 \mathrm{spp}$ of
Ulvophyaceae (15\%), 5spp of Bascillariophyaceae (12.5\%), 3spp each of Zygnematophyaceae and Chlorophyaceae $(7.5 \%)$. From Bolan river district KarchhiBalochistan 10 new records of fresh water algal taxa were explained, and belong to division Chlorophyta by [15].

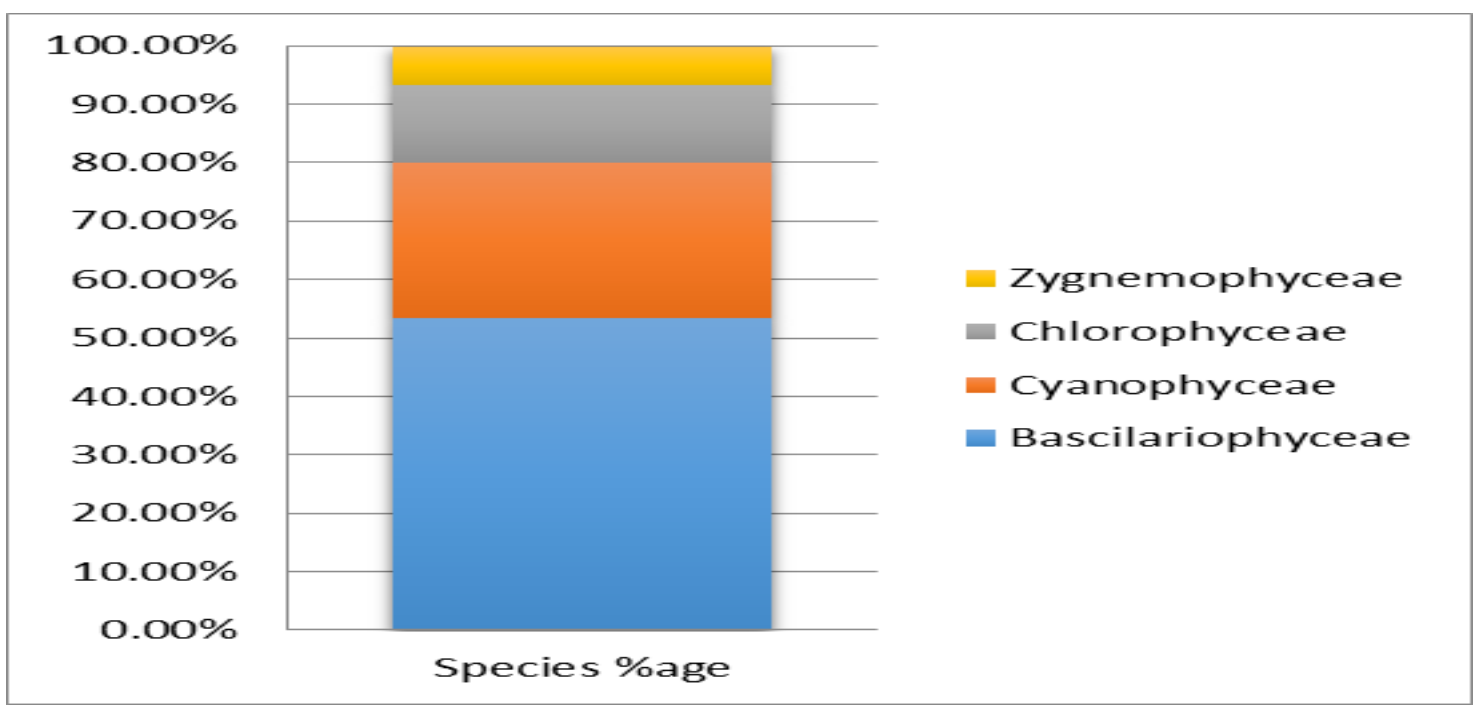

Figure 1. It shows us the relative percentages of 4 different classes in the selected area

\section{Peshawar}

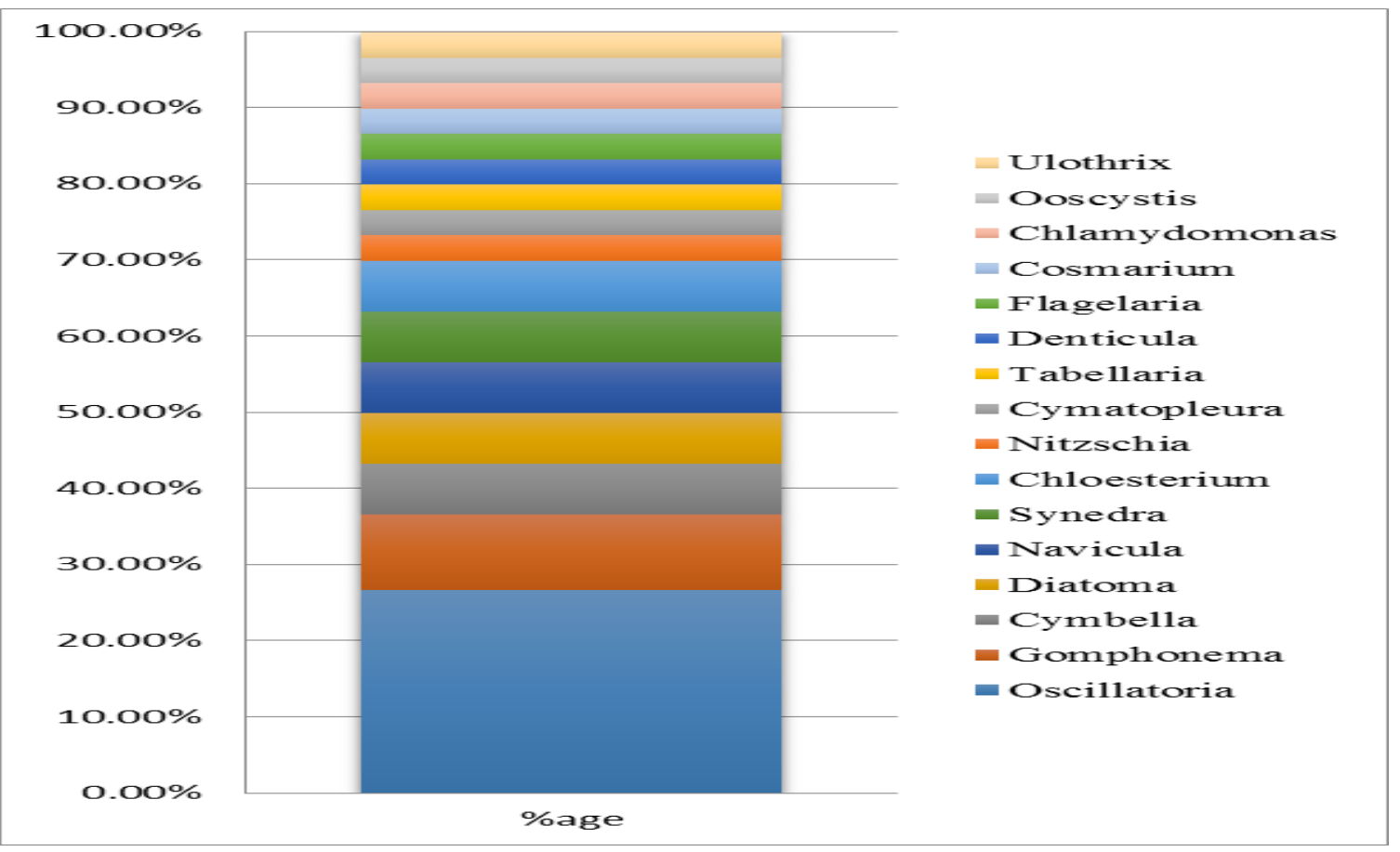

Figure 2. It represents the number of Genera and their percentages in the selected area Peshawar 
Table 3. Occurrence of species in the selected areas of Peshawar i.e. Hayatabad, Gulbahar and Ringroad

\begin{tabular}{|c|c|c|c|c|}
\hline S. No & Species Name & Hayatabad & Gulbahar & Ring road \\
\hline 1 & G.sphaerophorum & + & - & - \\
\hline 2 & G.ventricosum & _ & _ & + \\
\hline 3 & G.olivaceum & _- & + & + \\
\hline 4 & C.cymbiformis & + & + & + \\
\hline 5 & C.tumida & + & + & + \\
\hline 6 & D.anceps & $\ldots$ & $\ldots$ & + \\
\hline 7 & D.vulgaris & + & + & + \\
\hline 8 & N.cryptocephala & _- & + & _ \\
\hline 9 & N.salinarum & + & + & _ \\
\hline 10 & S.ulna & $\ldots$ & $\ldots$ & + \\
\hline 11 & S.rumpens & + & + & _ \\
\hline 12 & N.hungaria & + & + & + \\
\hline 13 & F.capucina & + & + & + \\
\hline 14 & C.solea & + & _- & _- \\
\hline 15 & T.flocculosa & + & + & + \\
\hline 16 & D.tenuis & - & _ & + \\
\hline 17 & C.globosa & _- & + & + \\
\hline 18 & C.contractum & + & + & $\ldots$ \\
\hline 19 & O.borgei & _ & + & + \\
\hline 20 & U.cylindricum & - & - & + \\
\hline 21 & O.sancta & + & + & $\ldots$ \\
\hline 22 & O.tenuis & + & + & $\ldots$ \\
\hline 23 & O.princeps & + & $\ldots$ & + \\
\hline 24 & O.formosa & + & + & _ \\
\hline 25 & O.chilkensis & _ & + & _ \\
\hline 26 & O.amphibia & _ & - & + \\
\hline 27 & O.agardhii & + & $\ldots$ & + \\
\hline 28 & O.angusta & - & + & _ \\
\hline 29 & C.lanceolatum & - & + & + \\
\hline 30 & C.moniliferum & + & _ & + \\
\hline
\end{tabular}

+ Presence,_Absence

PLATES OF REPRESENTED SPECIES

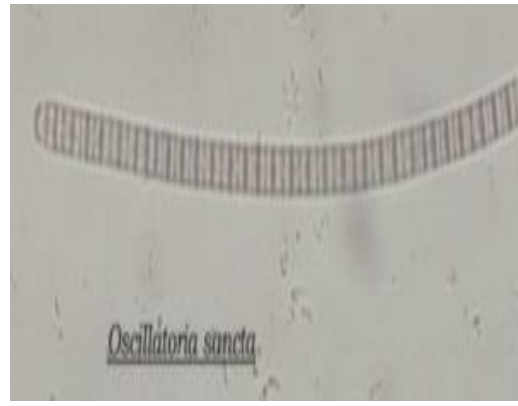

Figure 1. Oscillatoria sancta

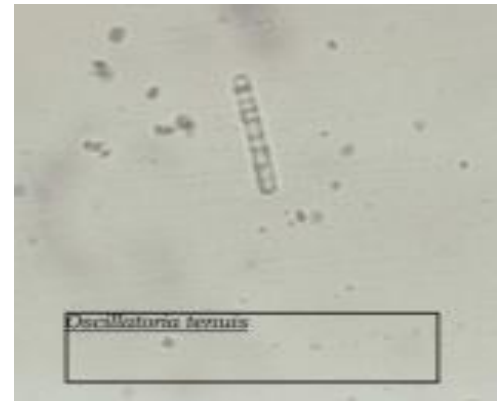

Figure 2. Oscillatoria tenuis

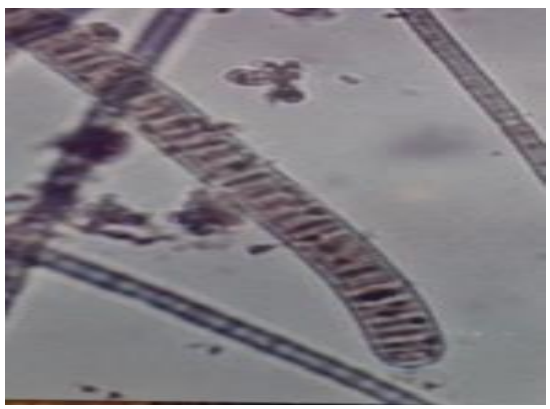

Figure 3. Oscillatoria princeps 


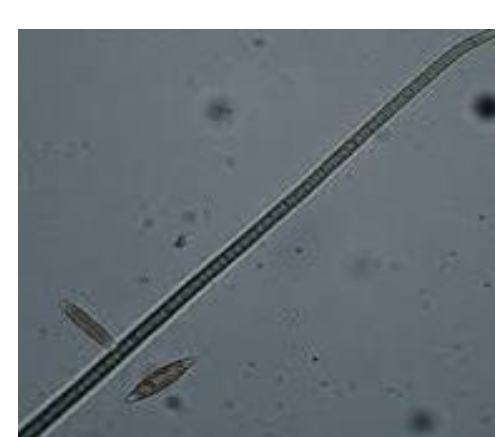

Figure 4. Oscillatori aformosa

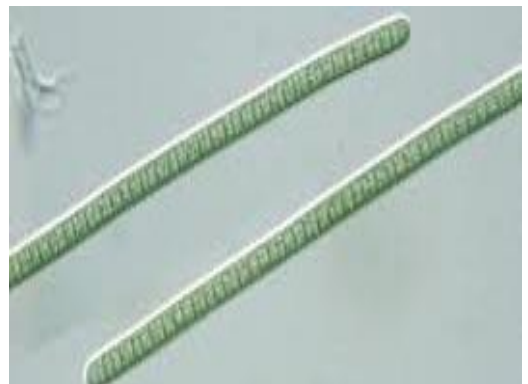

Figure 7. Oscillatoriaagardhii

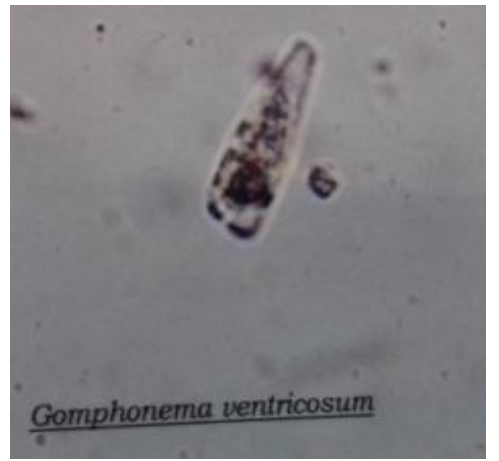

Figure 10. Gomphonema ventricosum

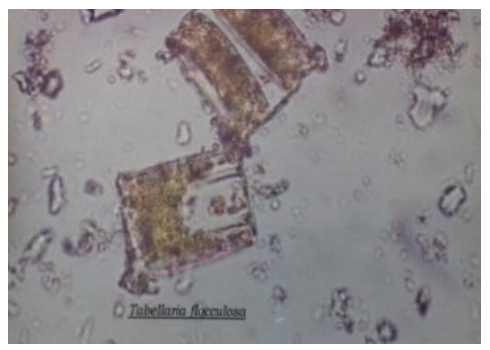

Figure 13. Tabellaria flocculosa

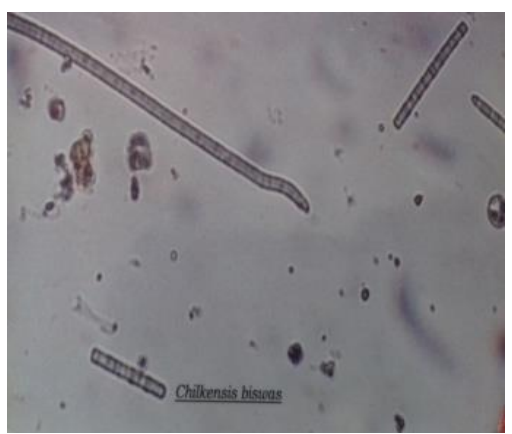

Figure 5. Oscillatoriac hilkensis

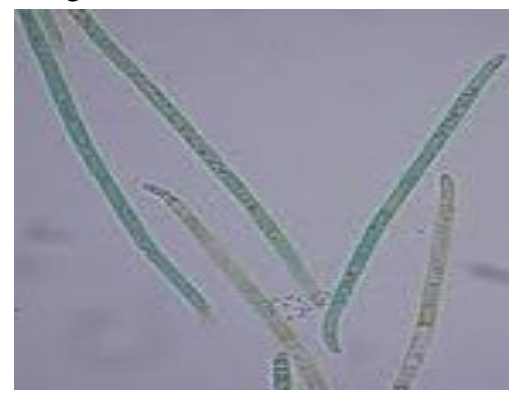

Figure 8. Oscillatotria angusta

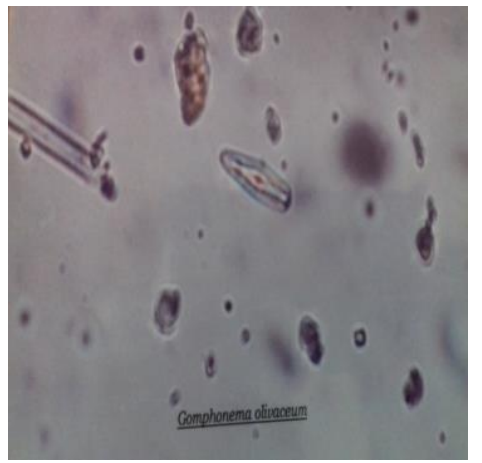

Figure 11. Gomphonema olivaceum

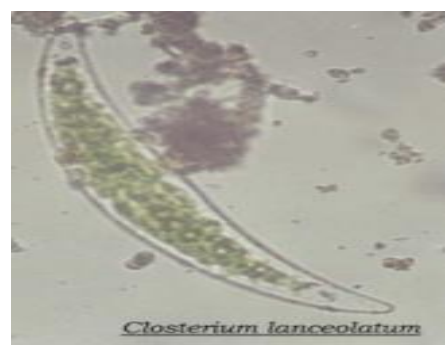

Figure 14. Chlosterium lanceolatum

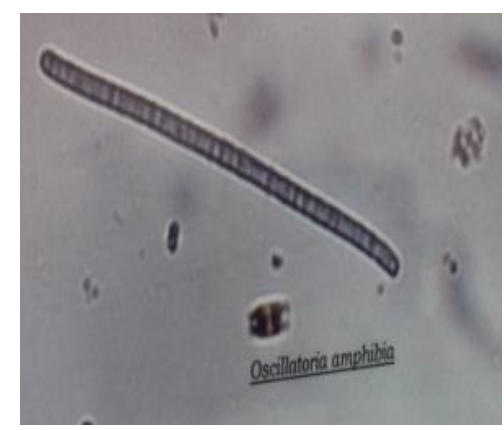

Figure 6. Oscilatoria amphibia

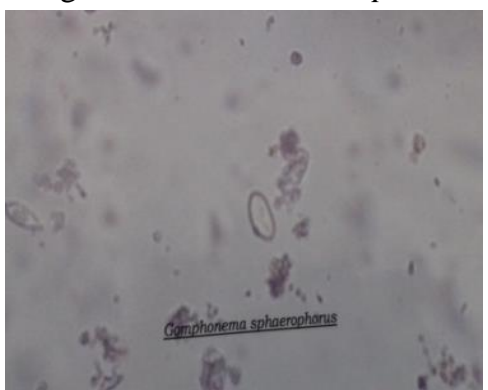

Figure 9. Gomphonema sphaerophorus

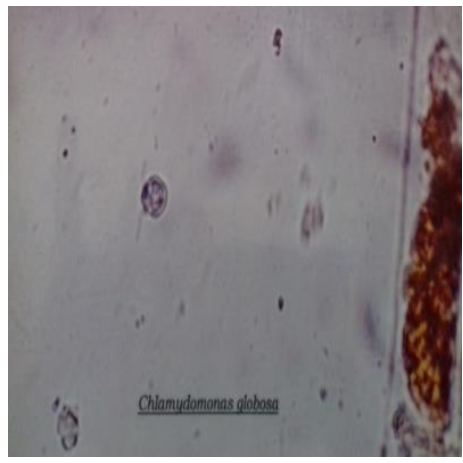

Figure 12. Chlamydomonas globosa

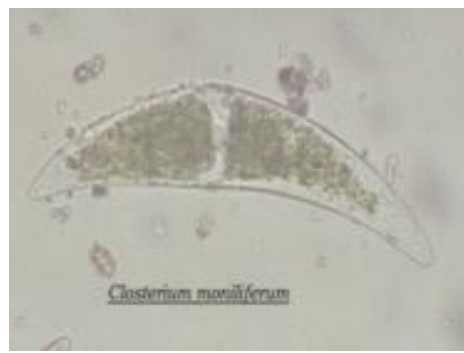

Figure 15. Chloesterium monileferum 


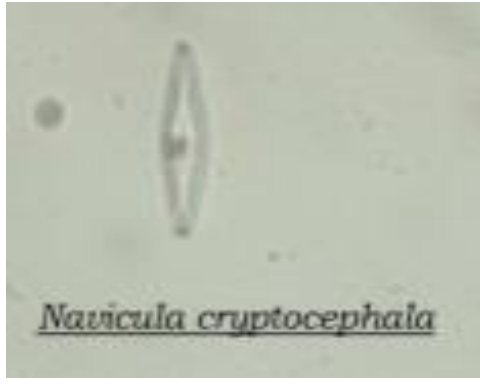

Figure 16. Navicula cryptocephala

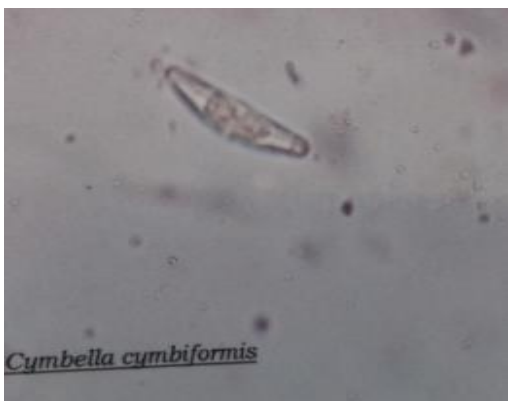

Figure 19. Cymbella cymbiformis

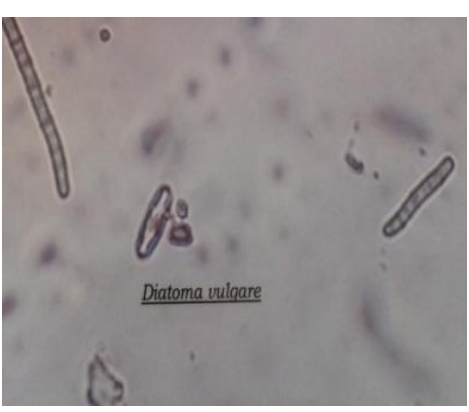

Figure 22. Diatoma vulgaris

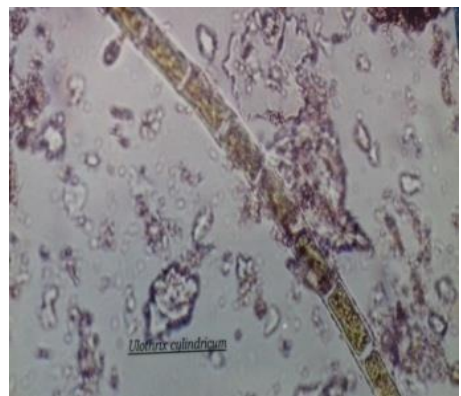

Figure 25. Ulothrixcylindricum

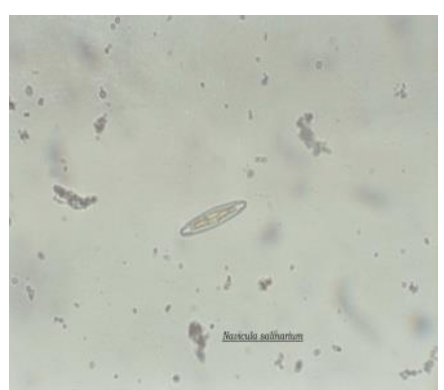

Figure 17. Naviculasalinarum

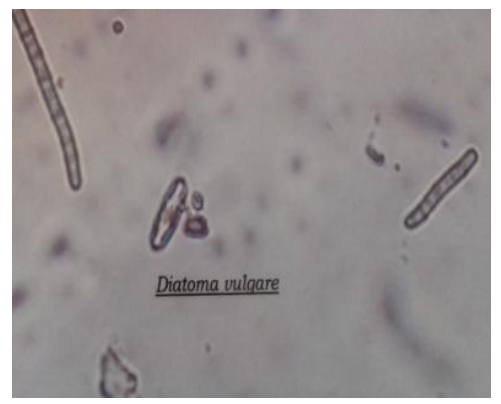

Figure 20. Cymbella tumida

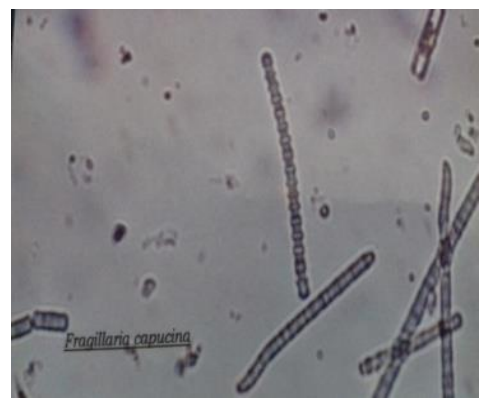

Figure 23. Flagilaria capucina

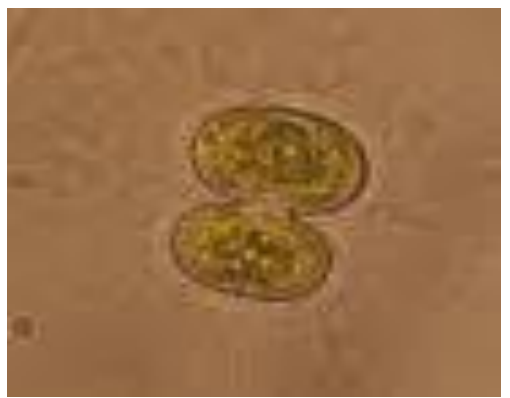

Figure 26. Cosmarium contractum

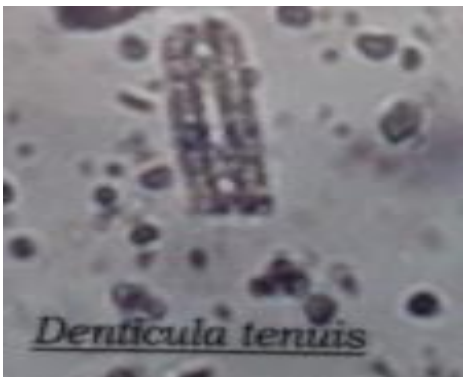

Figure 18. Denticula tenui

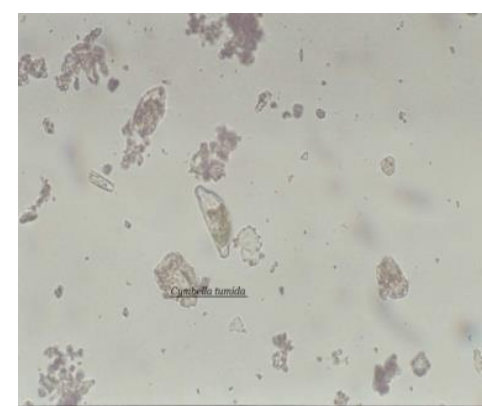

Figure 21. Diatoma ancepas

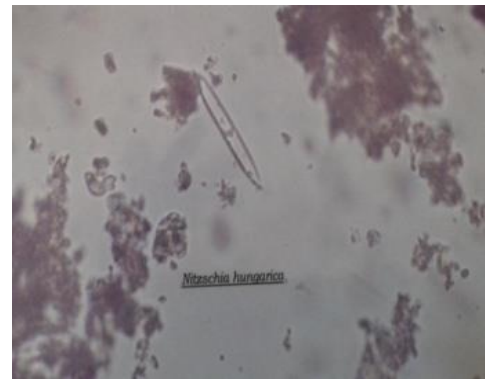

Figure 24. Nitzschia hungarica

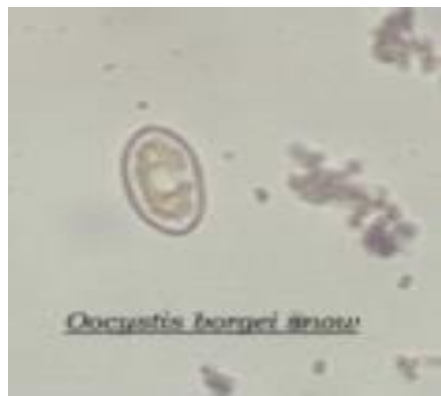

Figure 27. Oocystis borgeii snow 


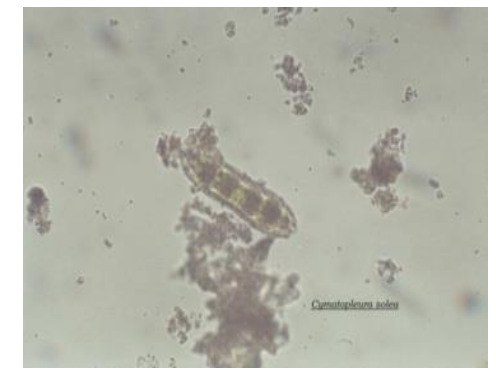

Figure 28. Cymatopleuras olea

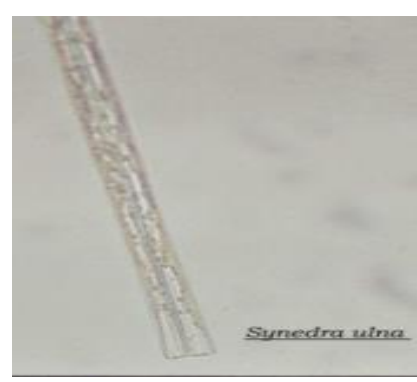

Figure 29. Synedra ulna

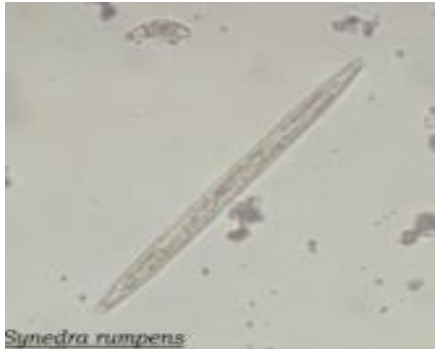

Figure 30. Synedra rumpens

\section{Conclusion}

Peshawar valley and its remote areas contain lakes, streams and other fresh water bodies where the microalgal species is an abundance. The current investigation included altogether 30 species of algae belonging to 4 classes having 16 genera are collected from various fresh water habitats in the Peshawar District including Gulbahar, Hayatabad and Ringroad. The present research shows that district Peshawar is rich of algal floras, further studies and research is needed in the other sites of valley.

\section{Author's contributions}

Conceptualized and designed the study: M Shuaib, Field work carried out by: KSU Din, Analyzed the data: M Shuaib \& F Hussain, Contributed to the editing and interpreting of the data: KSU Din, Draft of the manuscripts: M Shuaib \& F Hussain.

\section{Acknowledgment}

I am thankful to the Botany department Qurtaba University Peshawar and my supervisor Dr. Fida Hussain for providing me opportunity of conducting the current research work. I am also thankful to the reviewers for their valuable comments.

\section{References:}

1. Haq WU, Zarina A, Hassan MU \& Shameel M (2009). Taxonomic study of the genus Closterium (class Desmidophyceae Shameel) from northeastern areas of Pakistan. Proceedings of the Pakistan Academy of Sciences 46(2): 57-67.
2. Hussain F, Masud SM, Shah F, Hadi F, Zaman A \& Wazir SM (2009). Some blue green algae from rice fields of Asota Sharif, District Swabi, Pakistan. Pak J Plant Sci 15: 45-47.

3. Khalid MN, Mustafa S \& Saleem S (2010). Studies on bioactivities and phycochemistry of Microcystis aeruginosa (Cynophycota) from Sindh. Pak J Bot 42: 2635-2646.

4. Bellinger EG \& Sigee DC (2010). Freshwater algae identification and use as bioindicators. John Wiley \& Sons, Ltd, The Atrium, Southern Gate, Chichester, West Sussex PO19 8SQ U.K pp 271.

5. Khair UN \& Sarim FM (2006). Some fresh water algae from Kalash Valleys Chitral. Pakistan. Pak J Plant Sci 13:41-47.

6. Nawaz A \& Sarim FM (2004). The freshwater algae of Swat River. Puta $J$ 10: 181- 183.

7. Zaman A \& Hussain F (2006). Impact of water quality on the algal diversity during winter season in Peshawar valley, Pakistan. Int $J$ Phycol Phcochem 2(1): 77-86.

8. Leghari SM (2001). Some fresh water green filamentous algae (Chlorophyta) and Dinoboroncylindrica (Chrysophyta) from Lakes and Riverin Ponds of Sindh, Pakistan. Online J Biol Sci 1:145-149. 
9. Rehman MK (2012). The impact of water pollution on the growth and distribution of green algae (Chlorophyta) in River Kabul District Peshawar. MPhil Thesis, Islamia College, Peshawar.

10. Shah SZ, Ahmad N, Akhtar N, Khan I \& Khan SA (2001). Studies on Ulotrichales of District Peshawar, NWFP, Pakistan. Scientific Khyber 14 (2): 73-78.

11. Khan $M$, Hussain $F$ \& Musharaf $S$ (2011). A fraction of fresh water algae of Kalpani stream and adjoining area of district Mardan, Pakistan. Inter J Bio sci 1(3): 45-50.

12. Zarina A, Shameel M \& Naz S (2010). Distribution of Freshwater Blue-Green
Algae (Cyanophyta) in N. Pakistan. Int J Algae 12(3): 257-270.

13. Ali A, Shinwari ZK \& Sarim FM (2010). Contribution to the algal flora (Chlorophyta) of fresh waters of district Swat. NWFP, Pakistan. Pak $J$ Bot 42(5): 3457-3462.

14. Yaseen T, Zaib S, Sarim FM, Shakeel M, RahimF \& Begum HA (2016). Fresh water algae of Maidan, District Dir, Khyber Pakhtunkhwa Pakistan. Pure and Applied Biology 5(3): 499-510.

15. Abbas M, Sumalani \& Asrar M (2014). Two new freshwater algal records from district Kachhi of Balochistan, Pakistan. Sci Tech and Dev 33 (3): 137-141. 